\title{
ECOFRIENDLY UTILIZATION OF BY PRODUCTS FROM BANANA PEEL IN FOOD PRODUCTION AND OTHER INDUSTRIAL APPLICATIONS. A REVIEW
}

\author{
Muhammad Farooq ${ }^{1}$, Rabia Anwar ${ }^{2}$, Rizwan Shukat ${ }^{2}$, Syed QamarAbbas $^{2}$, Naila Ilyas ${ }^{3}$, Moale \\ Cristina ${ }^{4}$, Wang Yunyang ${ }^{1 凶}$ \\ ${ }^{1}$ College of Food Science and Engineering, Northwest A\&F University, Yangling, Shaanxi712100, PR China \\ ${ }^{2}$ Department of Food Technology National Institute of Food Science and Technology \\ University of Agriculture Faisalabad, Pakistan \\ ${ }^{3}$ Graduate School of Chinese Academy of Agricultural Sciences, Beijing 100081, China \\ ${ }^{4}$ Research Station for Fruit growing Constanta (RSFG) 907300 Valu Lui Traian Pepinierei Street, No 25, Romania \\ ${ }^{\bowtie}$ Wy10421@163.cm,Farooq.fst28@gmail.com \\ https://doi.org/10.34302/crpjfst/2021.13.4.12

\begin{tabular}{ll}
\hline Article history: & ABSTRACT \\
Received: & The banana (Musa Sapientum) is a member of the Musaceae family. The \\
$\quad$ 8 August 2021 & nutritional value of this fruit and its peels is significant. Every year, 36 \\
Accepted: & million tonnes of banana peel are produced. Starch, bioactive substances, \\
24 August 2021 & anti-oxidants, pectin, cellulose, minerals, phenolic acids, flavonoids, \\
Keywords: & carotenoids, biogenic amines, and other phytosterols are all found in \\
Banana peel; & banana skin. Lipids, carbs, protein, dietary fibers, and a variety of other \\
Preservative; & essential components are also present. It contains anti-nutritional elements \\
Bioethanol production; & such as hydrogen cyanide, oxalate, phytate, and saponin, but only in trace \\
Dietary content; & amounts, with the exception of saponin. Banana peel can be used to make \\
Livestockfeed; & buns, bread, pasta, confectionaries, and gluten-free items in the culinary \\
& sector. It's also utilized as bio substrate, as well as for medical uses, \\
& livestock feed, fertilizer, and bio substrate. Peel can also be used for \\
& various reasons, such as removing Cr (IV) and producing bio-Ethane and \\
& bio-methane. \\
\hline
\end{tabular}

\section{Introduction}

Musa Sapientum, also known as banana, is a member of the Musaceae family. It originated in the tropical reign of southern Asia and is currently farmed across the tropics. Musa Sapientum can reach a height of 2-8 meters and has leaves that are around 3.5 meters long. Its pseudostem produces the single bunch of bananas before it dried and replaced by fresh ones. Fruits grow in a cluster that hangs from the ceiling, with twenty fruits per tier and three to twenty tiers each bunch. The skin protects the fruit (Anhwange and colleagues, 2009).

The banana is a popular fruit that is well-known for its nutritional value. (Aurorae and colleagues, 2009). Climacteric fruit is a type of fruit. This fruit is consumed fresh and processed into various items on a small and industrial scale. (Vu et al 2016.). Banana carbohydrate (both starch and non-starch) has a poor digestion, making it a great ingredient for food preparations. A total of 102 million tonnes of bananas are produced each year. Because banana peel accounts for $35 \%$ of the total weight of the fruit, about 36 million tonnes of banana peel are produced each year. (Vu et al 2016.). The banana is said to have originated in Southern Asia's tropical regions, and it is currently grown all over the world. Anhwange (2008, Anhwange, Anhwange, Anhwange, Anhwang described that banana is the most popular fruit, its world fruit production is accounting for $16.8 \%$, with in apple, orange, and each accounting for 11.4 
percent.(Pereira and Maraschin 2015). Banana production has been increased dramatically in last 20 years, in 2013. (Vu et al 2018). Asia is the world's largest banana. From 46 million tonnes in 1993 to 105 million tonnes in 2013, there has been a steady increase. (Vu and colleagues, 2018). Asia is the world's top banana producer, accounting for over 57.3 percent of worldwide output, with America, Africa, Oceania, and Europe following closely after. They generate the least, accounting for less than 0.3 percent of world output. Production has increased as a result of increased demand, population growth, expansion of agricultural areas, and productivity. ( $\mathrm{Vu}$ et al 2018).

The major player of the banana industry is Pakistan, containing a land area of 349000 ha, with a total output and productivity of 29.7 million tons/ha, respectively. In Sindh province, 90 percent of the land is in the country's South East Asia. (Memon et al., 2015). According to FAO figures, Asia is the world's greatest banana producer, accounting for 54.4 percent of global banana production, with an average banana intake per capita of $12 \mathrm{~kg}$. Banana is one of the world's most significant food crops, behind rice, wheat, and maize. (Khoozani et al 2019.)

Banana peel is the most common byproduct, accounting for about $40 \%$ of the fruit total weight. (Agama-Acevedo et al. 2016, Agama-Acevedo et al. Until today, banana peels were discarded as waste, contributing a significant amount of organic material to landfills. Since the banana peel has been mostly focused by researcher, he has begun extracting and isolating key components for use in food enrichment and other applications. (Agama-Acevedo et al. 2016, Agama-Acevedo et al. Peel contains starch, bioactive substances, pectin, cellulose, and a variety of vital minerals and components. (Singh et al., 2016). Several substances, including phenolics, flavonoids, phytosterols, carotenoids, biogenic amines, and other phytochemicals are found in in peel (Pereira and Maraschin 2015). The peel of a banana has higher nutritional fibre. Dietary fiber is a non-digestible carbohydrate polymer, which can be divided into two categories according to its water solubility: soluble fiber (pectin and some hemicellulose) and insoluble fiber (cellulose, lignin, and resistant starch). (Khoozani et al 2019). Burns, diarrhea, ulcers, inflammation, diabetes, cough, snake bites, and excessive menstruation are just a few of the problems that banana peel is used to treat. (Pereira \& Maraschin 2015) Banana peels also include more dietary fibre and phenolic compounds, as well as anti-oxidants, antimicrobial, and antibacterial capabilities. Anjum, Sundaram, and Rai (Anjum, Sundaram, \& Rai, 2014). The content of phenolic compounds in banana peel was $4.95-47 \mathrm{mg}$ garlic acid equivalent/g dry matter (mg GAE/g DM). These chemicals have been associated to health advantages such as the prevention of cardiovascular illnesses, diabetes, cancer, and obesity (Hernández-Carranza et al., 2016). (Vu and colleagues, 2018). Gallocatechin, an antioxidant found in banana peel enriched with natural antioxidants. Gallocatechin is found in higher concentrations in banana peel (about 158 mg per $10 \mathrm{~g}$ dry weight) and has the strongest antioxidant effect against lipid auto oxidation. Someya and colleagues (Someya et al., 2002). Peel contains 0.9 percent, 1.7 percent, 59 percent, and 31.70 percent protein, fat, carbs, and crude fibre, respectively. The findings showed that banana peels are a rich source of carbs and fibre. Because it contains more fiber, it aids in the relief of constipation and enhances overall health. The banana peel moisture content is 6.7 percent. This is low value, and it could be because of the harvesting time (Vu and colleagues, 2018). The low score indicates that banana peel has a long shelf life without mold growth. The amount of ash in the product is 8.50 percent. The amount of organic matter in the soil is approximately 91.50 percent. Organic matter is a metric for a plant's nutritional worth (lipids, proteins, and carbohydrates).Vu and colleagues, 2018). Banana peels have a high nutritional value, indicating that they are a good source of nutrients. (Anhwange and colleagues, 2009) 
The potassium content of Musa Sapientum peel is higher than that of other minerals $(78.10 \mathrm{mg} / \mathrm{g})$. The concentrations of peel calcium, sodium, manganese, iron, rubidium, bromine, strontium, zirconium, and niobium 19.20, 24.30, 76.20, 0.61, 0.21, $0.04,0.03,0.02$, and 0.02 , respectively. If the peels are properly developed and processed, they can be a good source of high-quality carbohydrates and minerals at a low cost. $\mathrm{Vu}$ and colleagues, 2018). Because of its high potassium concentration, peel can assist to maintain blood pressure and balance bodily fluids, as well as control kidney failure, cardiac difficulties, and respiratory difficulties. Because iron transports oxygen to cells, it is required for energy production, collagen formation, and the normal functioning of the immune system. Manganese aids in the development of skeletal and cartilage tissue. (Khoozani et al 2019.) Bromine, rubidium, strontium, zirconium, and niobium are non-essential minerals with concentrations ranging from 0.21 to $0.02 \mathrm{mg} / 100 \mathrm{~g}$. The results show that banana peel has relatively low non-essential mineral concentrations. (Anhwange and colleagues, 2009). The peel of a banana has more dopamine than the pulp. Dopamine is a bioactive molecule that regulates hormones in glycogen metabolism. (Khoozani et al 2019.)

Anti-nutrients are also detected in banana peel, indicating that hydrogen cyanide concentrations are $1.33 \mathrm{mg} / \mathrm{g}$. Acids react with metal cyanides to produce hydrogen cyanide, which is exceedingly deadly. A large quantity of hydrogen cyanide can kill you in a matter of minutes, while smaller doses produce throat and chest stiffness, palpitation, and muscle weakness. However, they are present in the range of 0.5 to $3.5 \mathrm{mg} / \mathrm{g}$ and are listed as a safety limit. The oxalate content was nearly 0.51 milligrams per gram. (Kumar et al., 2012). Oxalate consumption is linked to kidney illness, which can lead to death, as well as a reduction in the availability of important minerals like calcium. When compared to the $0.7 \mathrm{mg} / \mathrm{g}$ reported for cocoyam, the result obtained is low. The amount of phytate in each gram was found to be $0.28 \mathrm{mg} / \mathrm{g}$. (Anhwange and colleagues, 2009). This finding is low when compared to the maize and sorghum results of 146-353, 206-208mg/g, respectively. Saponin content was found to be 24 percent. Consumption of saponin can cause sensory system paralysis. It has been discovered that it inhibits pig and poultry growth while increasing cholesterol excretion in the body. When compared to the 3.00 percent described as the lowest safe amount for animals, particularly cattle, the result achieved is significantly high. Except for saponin, the antinutrient content of the peel has been studied and found to be minimal. This suggests that, if properly handled, the peels could be a useful source of feed for cattle. (Anhwange and colleagues, 2009).

Banana peel is used in traditional medicine.

For decades, the peel of a banana has been used as a herbal treatment to treat a number of ailments including burns, ulcers, coughs, and diarrhea. (Pereira \& Maraschin, 2015).

For instance, burn wound healing has been healed by wrapping a ripe banana peel around the area to lessen pain as well as swelling (Pereira \& Maraschin, 2015). Banana peel has been proved to be an excellent cure for reducing inflammation and swelling after mosquito bites. (Kumar et al., 2012)The banana peel's antibacterial and antibiotic characteristics, and further research into these biological activities and bioactive components is required. Unripe banana peels have also been shown to be useful in the treatment of diarrhea. The peel works as an antacid against stomach ulcers. (Kumar et al., 2012).

Flavonoid component leucocyanindin found in banana peel has been shown to thicken the stomach's mucous membrane layer.(Imam \& Akter, 2011). Furthermore, the peel is used to prevent and treat a variety of illnesses, including depression (linked to the tryptophan concentration in bananas), anemia (high iron concentration increases hemoglobin production), and high blood pressure (peel high amount of potassium and low amount of salt). (Kumar et al., 2012; Kumar et al., 2012). Furthermore, the banana skin contains high fructose oligosaccharides, which are prebiotics 
that feed healthy bacteria in the colon. (Kurtolu and Yildiz 2011) by creating vitamins and digesting enzymes, these beneficial bacteria boost the human body's ability to absorb nutrition. (Walker and Duffy 1998). As a result, banana peel has a lot of potential as a traditional medicine. $(\mathrm{Vu}$ et al 2018).

\section{Livestock feed}

Major nutritional components such as carbohydrates, proteins and lipids at higher concentration in banana peel and account for $91.50 \%$ of dry weight. Indigestible fiber is also present in material at high level. (Anhwange, 2008). More than 9 minerals are also present some anti-nutritive component is also present such as hydrogen cyanide but present in minor than safe limit $(0.5-3.5 \mathrm{mg} / \mathrm{g})$. Banana peel is used as livestock feed and it contains similar quality of some ingredients with in soybean, cassava used for feeding pigs (Tartrakoon, Chalearmsan, Vearasilp, \& ter Meulen, 1999).

\section{Manure}

Traditionally banana skin was used as manure by replenish the soil nutrients simply by decomposing. Banana skin produces many types of organic fertilizer because of higher demand of bio fertilizers and biological advances. (Kalemelawa et al., 2012; Pangnakorn, 2006). Under aerobic and anaerobic conditions when banana peel is dumped with cow dung, poultry litter and earth worms then composed. This organic fertilizer contains high potassium $(>100 \mathrm{~g} /$ $\mathrm{kg})$ and nitrogen $(>2 \%)$, which is effective for all kinds of plants. (Pangnakorn, 2006).

\section{Bio-substrate}

By using polymer enzyme and acids cellulose can be hydrolyzed and has been used to produce sugars, organic acids, fuels and enzymes. As banana peel consists of high level of cellulose so it has been used as bio-substrate (Oberoi et al., 2011). For edible mushrooms cultivation and wine production banana peel has been used as substrate. (Padam et al., 2014). Banana skin has been used as substrate to produce xylitol, a sugar that has beneficial properties and used as alternative source of conventional sweetners. (Rehman et al., 2013).

\section{Utilization of banana peel in food industry. Production of buns}

Substitution of refined wheat flour with banana peel fibers with, buns were prepared. The supplementation of refined wheat flour $(30 \mathrm{~g})$ with banana peel fibre up to 40 and $10 \%$ blend were prepared. Other ingredients that are include were sugar $5 \mathrm{~g}$, yeast $5 \mathrm{~g}$, milk powder $5 \mathrm{~g}$, water $20 \mathrm{ml}$ and oil $10 \mathrm{ml}$ or $5 \mathrm{~g}$ butter, $50 \mathrm{mg}$ salt. (Budhalakoti, 2019). Refined wheat flour and banana peel fibre were sieved and a uniform blend was made. Luke warm water were used to dissolve yeast and little amount of blend mixture was added to it. (Budhalakoti, 2019) Proofing of this mixture is done at $30^{\circ} \mathrm{C}$ for 1 or $1 / 2$ hours. Sugar was also added and remaining mixture was added to it and kneaded it to till soft smooth dough. Dough was again punched for few minutes. Dough was sheeted, rolled and molded. Then it was placed in greased sheet, covered with a wet cloth and allowed to rise in tin under $30^{\circ} \mathrm{C}$. Water was sprayed on the bun surface before putting it on oven. Bun was baked at $200^{\circ} \mathrm{C}$ for 10 minutes. After 10 minutes, bun was taken out from oven and allowed to cool. Buns that contain 10\% fiber were texturally acceptable and more palatable. (Budhalakoti, 2019)

\subsection{Bread production from banana and banana peel flour}

Processing of flour from banana and banana peel has similar steps. Due to high dietary fiber and bioactive compounds, these flours are used in food stuffs for remarkable functionalities. Bread that are produced from banana of banana peel flour has high value of starch, ash, protein and TDF. (Khoozani et al., 2019). In term of minerals the bread has more value of $\mathrm{Mg}, \mathrm{K}, \mathrm{Na}$, and $\mathrm{Ca}$. and increase inTDF and RS were also shown to have increased by $9 \%$ and $5 \%$, respectively, in the mucous membrane layer of the stomach. Adding GBPF and gluten to bread has the unfavorable effect of making it harder and stickier. Because of 
the deficiency of stability in gluten structure, cohesion, elasticity, and chewiness decrease when supplementing is done at $30 \%$. (Khoozani et al., 2019).

\subsection{Production of pasta}

Pasta products, like other foods, play a significant role in people's diets. In comparison to white bread or rice, pasta has a low glycemic index, a long shelf life, and is simple to prepare. (Nilsson et al., 2010) In 2009 spaghetti made with semolina flour that was enriched with different substitution of GBPF. Textural results indicate an increase in adhesiveness and chewiness that was because of release of amylose from starch during cooking. Pasta made with GBPF consists of $42.54 \%$ RS2 and high percentage of polyphenols and antioxidants. (Agama-Acevado et al., 2009). A combination of $15 \%$ sprouted flour and $15 \%$ GBPF provided best nutritional and technological attributes. (Krishnan and Parhabashankar 2010).

\subsection{Confectionaries production}

By addition of $60 \%$ GBPF in cake premix instead of wheat flour increases its shelf life over 4 months. The $\mathrm{pH}$ of the Premixture does not change. As well as harmful development, such as fungus and yeast. (Borges et al., 2010; Borges et al., 2010; Borges et al., 2010 Cakes prepared with fine GBPF particle sizes have superior nutritional characteristics without having a negative impact. (Segundo et al., 2017). In biscuits manufacturing a prior treatment of mashed peel together with DF increases softness. Even at $75 \%$ substitution there were not significantly change in organoleptic properties such as color, flavor, after taste and mouth feel. (Joshi 2007).

\subsection{As functional ingredient in yellow noodles}

Banana peel noodles are prepared by substitution of wheat flour and green Cavendish banana peel flour which were characterized for physiochemical properties and in vitro starch hydrolysis. Cooked noodles were assessed for estimated glycemic index, vitro hydrolysis index, color, $\mathrm{pH}$, and tensile strength. (Ramli et al., 2009). Banana peel noodles has higher elasticity but same tensile strength as of control. GI of glycemic index of banana peel noodles was lower than the control. Partial substitution of banana peel into noodles may be useful to control starch hydrolysis of yellow noodles. (Ramli et al., 2009)

\subsection{Gluten free products}

As the prevalence of gluten-related illnesses including celiac disease and dermatitis herpetiformis rises, so does the need for glutenfree products. If left untreated, it can lead to intestinal cancer, food shortages, and oxidative stress, thus choosing gluten-free goods with added nutritional value is crucial. (Wang et al., 2017; Wang et al., 2018). The addition of 47 percent banana peel flour to a $100 \mathrm{~g}$ pasta recipe resulted in pasta with more egg white and hydrocolloids. (Zandonadi and colleagues, 2012). Gluten-free bread and pastries are also available; however, their limited qualities necessitate further research into GF starch-based items. Bioactive substances are prevalent in GF diets; as most starchy foodstuffs lack technical features. Torres et al. (Torres et al., 2017).

\subsection{Natural Preservative}

Because of its antibacterial and antioxidant qualities, banana peel could be used as a natural preservative in food products. To improve the quality and shelf life of poultry meat and fish oil, for example, extracts were added. (Anal and colleagues, 2012)

Banana extracts were found to have preservation properties comparable to synthetic preservatives such as Butylated hydroxytoluene (BHT) and Butylated hydroxyanisole (BHA) (BHA). (Devatkal et al., 2014)

\subsection{Other uses of banana peel}

Heavy metals such as lead, chromium, copper, cadmium, and zinc are always a concern to humans, animals, and the environment. The skin of a banana has been reported to be an efficient heavy metal absorber. Synthetic colors are also 
absorbed by banana peel (Castro et al., 2011). (Osma and colleagues, 2011)

Banana peel is a good source of extractable pectin, which can be used in the food sector for a variety of purposes. (Oliveria and colleagues, 2015) The main aromatic ingredient used in banana taste is Isoamyl acetate, which is also derived from banana peel. (2015, Ji et al.) In the food sector, banana flour is used as a carbohydrate source or a thickening ingredient. Alkarkhi et al. (Alkarkhi et al., 2011). Because banana starch is regarded superior to maize starch, it has a higher market value. Padam et al. (Padam et al. 2014) Selective removal of Cr (VI) from industrial wastewater:

Banana peel a commonly produced fruit waste used for the removal of $\mathrm{Cr}$ (VI) from industrial waste water. Chromium is waste water from metal fishing and chromo plating industries. (Torres et al., 2017) By ingestion of high level of $\mathrm{Cr}$ (IV) causes glomuler damage, tubular and kidney damage. So its removal is essential from waste water. Maximum acceptable limit for drinking water by WHO is $0.05 \mathrm{mg} / \mathrm{l}$. Banana peel is used as economical sorbent. (Memon et al., 2008) Initial metal ion concentration, parameters $\mathrm{pH}$, contact time and temperature were investigated and efficient absorption 95\% within $10 \mathrm{~min}$ were determined. (Torres et al., 2017) Optimal absorption occurs at $\mathrm{pH} 2$ and binding metal ion was $\mathrm{pH}$ dependent. By using $5 \mathrm{ml}$ of $2 \mathrm{M} \mathrm{H}_{2} \mathrm{SO}_{4}$ all retained species were eluted and by using flame atomic absorption and ultraviolet visible spectroscopy technique total amount of chromium and $\mathrm{Cr}$ (IV) were analyzed. (Itelima et al., 2013). Partitioning behavior for the system at different temperature were used to describe by Langmuir and dubininredushkevich isotherms. By using banana peel kinetics and thermodynamics of $\mathrm{Cr}(\mathrm{VI})$ removal were also studied. (Memon et al., 2008)

\subsubsection{Bio-Ethanol production from banana peel}

Banana peels that are waste of fruit industry and present in abundance and are used to produce Bio-Ethanol. Peels were subjected to scarification and fermentation simultaneously for 7 days by using co-culture of Aspergillus Niger and Saccharomyces Cerevisea. (Itelima et al., 2013) Ethanol yield, reducing sugar concentration, cell dry weight and biomass yield were determined after 24 hours' interval. After 7 days of fermentation was banana peel had biomass yield of 1.60 OD. $0.20-0.82 \mathrm{mg} / \mathrm{cm}^{3}$ and ethanol yield were about $7.45 \% \mathrm{v} / \mathrm{v}$. fruit waste that contain fermented sugars such as banana should be used for alternative source of energy. (Itelima et al., 2013)

\subsubsection{Bio methane production from banana peel}

Raw banana peel is also used for bio methane production. Physical treatment by grinding the peel into small pieces prior to anaerobic fermentation was used. Batch reactor was used under mesophilic conditions $\mathrm{pH} 7$ and different concentration of total solids used. (Pisutpaisal et al., 2014) Air and liquid samples were collected at 12 hours' interval for gas composition and volatile fatty acids analysis. At 7.5\% concentration of TS maximum yield and production of bio methane were $439 \mathrm{Ml} \mathrm{g} \mathrm{g}^{-1} \mathrm{TVS}$ and $5.31 \mathrm{Ml} \mathrm{hr}^{-1}$. Size reduction of banana peel and fungal pretreatment might improve the methane yield from banana peel fermentation in future work. (Pisutpaisal et al., 2014).

\section{Conclusions}

This assessment overlooks the effective use of banana peels, which are frequently discarded. The conversion of banana peel into numerous valuable applications in the food sector, for medicinal purposes, livestock feed, and the creation of bio ethane and bio methane was reviewed in this paper. The peel of a banana gives nutritious value to a variety of foods. The use of banana peels as a cheap and rich source of antioxidants, phenolic compounds, and minerals points to a future research direction of cost-effective and efficient nutrient recovery, usage, and enrichment. 


\section{References}

Agama-Avecado, E., Islas-Hernandez, J.J., Osorio-Diaz, P., Rendon-Villalobos, R., Utrillo Coella, R.G., Angulo, O. and Bello-Parez, L.A. (2009). Pasta with unripe banana flour: physical, texture and preference study. Journal of Food Science. 74, 263-267.

Agama-Acevedo, E., Sanudo-Barajas, J.A., Velez De La Rocha, R., GonzalezAguilar, G.A., Bello-Perez, L.A. (2016). Potential of plantain peels flour (Musa paradisiaca L.) as a source of dietary fiber and antioxidant compound. CyTAJournal of Food. 14(1), 117-123.

Alkarkhi, A. F. M., Ramli, S.B., Yong, Y.S., and Easa, A.M. (2011). Comparing physicochemical properties of banana pulp and peel flours prepared from green and ripe fruits. Food Chemistry. 129(2), 312-318.

Anal, A. K., Jaisanti, S. and Noomhorm, A. (2012). Enhanced yield of phenolic extracts from banana peels (Musa acuminate Colla $A A A$ ) and cinnamon barks (Cinnamomum varum) and their ant oxidative potentials in fish oil. Journal of Food Science and Technology. 51(10), 2632-2639.

Anhwange, B. A. (2008). Chemical composition of Musa Sapientum (Banana) Peels. Journal of Food Technology 6(1), 263-266.

Anhwange, B., Ugye J.T., Nyiatagher T.D. (2009). Chemical composition of Musa Sapientum (banana) peels). Electronic Journal of Environmental, Agriculture and Food Chemistry. 8(6), 437-442.

Anjum, S., Sundaram, S., Rai., G. (2014). Nutraceuticals application and value addition of banana (Musa paradisiaca L. Variety, "Bhusawal Keli") peel: A review. International Journal of Pharmacy and Pharmaceutical Sciences. 6(10), 81-85.

Aurore, G., Parfait, B., Fahrasman, L. (2009). Bananas, raw materials for making processed food products. Trends in Food Science \& Technology. 20(2), 78-91.in text is Aurorae, please use the same citation

Borges, AM., Pereira, J., Silva Junior, A., de Lucena, E.M.P. and De Sales, J.C. (2010). Stability of cake pre-mixture made with $60 \%$ of green banana flour. Cienc Agrotecnol. 34, 173-181.

Budhalakoti, N. (2019). Formulation and Standardization of Banana Peel Extracted Insoluble Dietary Fibre Based Buns. Current Journal of Applied Science and Technology. 32(2), 1-9.

Castro, R. S. D., Caetano, L., Ferreira, G., Padilha, P.M., Saeki, P.M.., Zara, M.J., Castro, L.F. (2011). Banana peel applied to the solid phase extraction of copper and lead from river water: Preconcentration of metal Ions with a fruit waste. Industrial \& Engineering Chemistry Research. 50(6), 3446-3451.

Devatkal, S. K., Kumboj R., Paul D. (2014). Comparative antioxidant effect of BHT and water extracts of banana and sapodilla peels in raw poultry meat. Journal of Food Science and Technology. 51(2), 387-391

Hernández-Carranza, P., Avila-Sosa, R., GuerreroBeltrán, J.A., Navarro-Cruz, A.R., CoronaJiménez, E., Ochoa-Velasco, C.E. (2016). Optimization of antioxidant compounds extraction from fruit by-products: Apple pomace, orange and banana peel. Journal of Food Processing and Preservation. 40(1), 103-115.

Imam, M. Z and Aktar, S. (2011). Musa paradisiaca L. and Musa Sapientum L.: A phytochemical and pharmacological review. Journal of Applied Pharmaceutical Science. 1(5), 14-20.

Itelima, J., Onwuliri, F., Onwuliri, E., Onyimba, I. and Orforji, S. (2013). Bio-Ethanol production from banana, plantain and pineapple peels by simultaneously scarification and fermentation process. International Journal of Environmental Science and Development. 4(2), 213-216.

Joshi, R.V. (2007). Low calorie biscuits from banana peel pulp. Journal of Solid Waste Technology and Management. 33 (1), 142147. 
Kalemelawa, F., Nishihara, E., Endo, T., Ahma, Z., Yeasmin, R., Tenywa, M.M. and Yamamoto, S. (2012). An evaluation of aerobic and anaerobic composting of banana peels treated with different inoculums for soil nutrient replenishment. Bioresource Technology. 126(1), 375-382. Please use alphabetical order, $\mathrm{y}$ is at the end on references

Khoozani, A. A., Birch, J. and Bekhit, A.E.A. (2019). Production, application and health effects of banana pulp and peel in the food industry. Journal of Food Science and Technology. 56(2), 548-559.

Krishnan, M. and Prabhasankar, P. (2010). Studies on pasting, microstructure, sensory, and nutritional profile of pasta influenced by sprouted finger millet (Eleucinaa coracana) and green banana (Musa paradisiaca) flours. Journal of Texture Studies. 41, 825-841.

Kumar, K. P. S., Bhowmilk, D., Duraivel, S., Uma Devi, M. (2012). Traditional and medicinal uses of banana. Pharmacology and Photochemistry. 1(3), 53-63.

Kurtoğlu, G and Yildiz, S. (2011). Extraction of fructo-oligosaccaride components from banana peels. Gazi University Journal of Science. 24(4), 877-882.not cited in manuscript text please correct

Memon, J. R., Memon, S.Q., Bhanger, M.I., Turki, A.E., Hallam, K.R., Allen, G.C. (2008). Banana peel: a green and economical sorbent for the selective removal of $\mathrm{Cr}$ (VI) from industrial wastewater. Colloids and Surfaces B: Bio interfaces. 70(1), 232-237.

Nilsson, A., Ostmen, A., Preston, T. and Bjork, I. (2008). Effect of GI vs content of cereal fiber on evening meal on glucose tolerance on subsequent standardized breakfast. European Journal of Clinical Nutrition. 62(1), 712-720.

Oberoi, H. S., Vadlani, P.V., Saida, L., Bansal, S. and Hughes, H.J. (2011).
Ethanol production from banana peels using statistically optimized simultaneous saccharification and fermentation process. Waste Management. 31(1), 1576-1584.

Oliveira, T. Í. S., Rosa, M.F., Cavalcante, F.L., Pereira, P.H.F., Moates, G.K., Wellner, N., Mazzetto, S.E., Waldron, K.W. and Azeredo, H.M.C. (2015). Optimization of pectin extraction from banana peels with citric acid by using response surface methodology. Acta Horticulturae.1088 (1), 541-546. Not in manuscript, please correct

Osma, F., Herrera, J.L.T., Couto, S.R. (2007). Banana skin: Anovelwaste forlaccase production by Trametes pubescens under solid-state conditions. Application to synthetic dye decolouration. Dyes and Pigments. 75(1), 32-37.

Padam, B. S., Tin, H.S., Chye, F.Y. and Abdullah, M.I. (2014). Banana by-products: An underutilized renewable food biomass with great potential. Journal Food Science Technology. 51(12), 3527-3545.

Pangnakorn, U. (2006). Valuable added the agricultural waste for farmers using in organic farming groups in Phitsanulok, Thailand. In: Proceeding of the prosperity and poverty in a globalized world-challenges for agricultural research, Bonn, Germany, October, 11-13

Pereira, A., Maraschin, M. (2015). Banana (Musa spp) from peel to pulp: Ethno pharmacology, source of bioactive compounds and its relevance for human health. Journal of Ethnopharmacolocy, 160(1), 149-163.

Pisutpaisal, N., Booniyawanich, S. and Saowaluck, H. (2014). Feasibility of bio methane production from banana peel. Energy Procardia. 50(1), 782-788.

Ramli, S., Alkharki, A.F.M., Yong, Y.S. and Easa, A.M. (2009). Utilization of banana peel as functional ingredient in yellow noodles. Asian Journal of Food and Agro-industry. 2(03), 321-329.

Rehman, S., Nadeem, M., Ahmad, F. and Mushtaq, Z. (2013). Biotechnological production of xylitol from banana peel and its impact on physicochemical properties of rusks. Journal of Agricultural Science and Technology. 15(4), 747-756. 
Segundo, C., Roman, L. Gomez, M. and Martınez, M.M. (2017). Mechanically fractionated flour isolated from green bananas ( $M$. cavendishii var. nanica) as a tool to increase the dietary fiber and phytochemical bioactivity of layer and sponge cakes. Food Chemistry. 219, 240-248.

Singh, B., Singh, J.P., Kaur, A. and Singh, N. (2016). Bioactive compounds in banana and their associated health benefits-a review. Food Chemistry. 206, $1-11$.

Tartrakoon, T. N., Chalearmsan, T., Vearasilp and Meulen, U. (1999). The nutritive value of banana peel (Musa Sapientum L.) in growing pigs. Paper presented at the proceedings of the Deutscher Trope tag.

Torres, MD., Arufe, S., Chenlo, F. and Moreira, R. (2017). Coeliac cannot live by gluten-free bread alone-every once in a while they need antioxidants. International Journal of Food Science and Technology. 52(1), 81-90.

Vu, H.T., Scarlett C.J., Vuong, Q.J. (2016). Effects of drying conditions on physicochemical and antioxidant properties of banana (Musa Cavendish) Peels. Drying Technology. 35(9), 11411151.

Vu, H. T., Scarlet, C.J. and Vuong, Q.V. (2018). Phenolic compound with in banana peel and their potential uses: a review. Journal of Functional Food. 40(1), 238-248.

Zandonadi, R.P., Botelho, R.B.A., Gandolfi, L., Ginani, J.S., Montenegro, F.M., and Pratesi, R. (2012). Green banana pasta: an alternative for gluten-free diets. Journal of Academic Nutrition and Diet.112 (1), 1068-1072.

Walker, W.A. and Duffy, L.C. (1998). Diet and bacterial colonization: Role of probiotics and prebiotics. The Journal of Nutritional Biochemistry. 9(12), 668675.
Wang, K., Lu, F., Li, Z., Zhao, L. and Han, C. (2017). Recent developments in gluten-free bread baking approaches: a review. Food Science and Technology. 37(1), 1-9.

Please order the refences in alphabetical order, European model, the last letter need to be S,T, $\mathrm{U}, \mathrm{V}, \mathrm{W}, \mathrm{X}, \mathrm{Y}$ and $\mathrm{Z}$ 